\title{
PENGARUH pH EKSTRAKSI TERHADAP RENDEMEN, SIFAT FISIKO-KIMIA DAN FUNGSIONAL KONSENTRAT PROTEIN KACANG GUDE (Cajanus cajan (L.) Millsp.)
}

\author{
Hesti Pratiwi ${ }^{1)}$, N. L. Ari Yusasrini ${ }^{2)}$, I Nengah Kencana Putra ${ }^{2)}$ \\ 1) Mahasiswa Ilmu dan Teknologi Pangan, Fakultas Teknologi Pertanian, Universitas Udayana \\ ${ }^{2)}$ Dosen Ilmu dan Teknologi Pangan, Fakultas Teknologi Pertanian, Universitas Udayana
}

Email : hestipratiwi46@gmail.com

\begin{abstract}
The purpose of this research are to know the effect of $\mathrm{pH}$ extraction on yield, physico-chemical and functional properties of pigeon pea protein concentrate, and also to know the appropriate $\mathrm{pH}$ extraction to obtain the best yield and properties of pigeon pea protein concentrate. The research was using Randomized Complete Design with $\mathrm{pH}$ extraction treatment which consist of five levels were 9; 9,5; 10; 10,5; and 11. The parameters were observed consist of yield, physical properties (lightness), chemical properties (protein and moisture), and protein's functional properties (water holding capacity, oil holding capacity, emulsion capacity and stability, and foaming capacity and stability). The result showed that $\mathrm{pH}$ extraction gave a significant effect to protein and moisture, and gave very significant effect to yield, lightness (L), water holding capacity, oil holding capacity, emulsion capacity, emulsion stability, foaming capacity and foaming stability of pigeon pea protein concentrate. The best properties of protein concentrate was found at sample which treatment of $\mathrm{pH} 10$ with a yield $17,29 \%(d b)$, lightness $(L) 18,84$, protein $86,15 \%(d b)$, moisture $7,96 \%(d b)$, water holding capacity $1,96 \mathrm{ml} \mathrm{H} \mathrm{H}_{2} \mathrm{O} / \mathrm{g}$ solid, oil holding capacity 2,62 $\mathrm{ml}$ oil/g solid, emulsion capacity $54,67 \%$, emulsion stability $54,83 \%$, foaming capacity $100 \%$, and foaming stability $38,19 \%$.
\end{abstract}

Keyword : Protein concentrate, pigeon pea, pH extraction, physico-chemical.

\section{PENDAHULUAN}

Konsentrat protein adalah bentuk protein murni dengan konsentrasi protein minimal $70 \%$ berat kering, produk ini hampir bebas dari karbohidrat, serat dan lemak sehingga sifat fungsionalnya jauh lebih baik daripada tepung (Koswara, 2009). Konsentrat protein memiliki beberapa peran baik dalam sistem biologis, sebagai sumber nutrisi, maupun sifat fungsionalnya dalam pengolahan pangan. Peranan sifat fungsional konsentrat protein dalam pengolahan pangan yaitu sebagai pengental, pembentuk gel, penstabil emulsi, pembentuk buih, pembentuk flavor, dan lain sebagainya (Kusnandar, 2010).

Bahan baku yang biasa digunakan dalam pembuatan konsentrat protein adalah tepung kedelai bebas lemak atau biji kedelai utuh (Koswara, 2009). Hingga saat ini, kebutuhan kedelai termasuk konsentrat protein kedelai sebagian besar masih dipenuhi oleh produksi luar negeri. Data yang diperoleh dari Badan Pusat Statistika (BPS) memperlihatkan volume impor bahan baku kedelai mulai tahun 20132017 terus mengalami peningkatan. Volume impor kedelai pada tahun 2013 dan 2014 secara berturut-turut yaitu 1,785 juta ton dan 1,965 juta ton (Anon., 2014), kemudian pada tahun 2015 dan 2016 volume impor kedelai mencapai 2,256 juta ton dan 2,261 juta ton (Anon., 2016), dan pada bulan Agustus 2017 volume impor kedelai sudah mencapai 1,725 juta ton atau sekitar $70 \%$ dari kebutuhan kedelai nasional (Anon., 2017). 
Mengacu pada permasalahan tersebut, perlu dibuat konsentrat protein dari kacangkacangan lokal sehingga dapat mengurangi impor kedelai. Indonesia memiliki berbagai jenis kacang-kacangan dengan kandungan protein berkisar antara 20-35\% (Koswara, 2009). Salah satu jenis kacang-kacangan lokal yang belum begitu banyak dimanfaatkan sebagai sumber pangan adalah kacang gude (Cajanus cajan (L.) Millsp.). Kacang gude memiliki kandungan protein yang cukup tinggi yaitu berkisar 23-26\% (Oshodi et al., 1985 dalam Emefiene et al., 2014), dengan kandungan asam amino esensial yang memiliki kemiripan dengan kedelai baik kualitas maupun kuantitasnya (Darmadjati dan Widowati, 1985). Kacang gude juga memiliki kelebihan dalam hal budidaya dibanding jenis kacang-kacangan lain yaitu toleran terhadap kekeringan, sesuai untuk berbagai jenis tanah baik subur, asam, mupun tanah yang bersalinitas dan basa (Fathurrahman, 2005). Nilai potensi produksi kacang gude nasional mencapai 2,5 ton/ha (Susila et al., 2012). Hal ini menunjukkan bahwa kacang gude juga berpotensi dikembangkan sebagai konsentrat protein.

Proses pembuatan konsentrat protein dapat dilakukan dengan ekstraksi menggunakan larutan alkali (alkaline extraction) yang diikuti dengan proses pengendapan protein (isoelectric precipitation). Prinsip dari proses alkaline extraction adalah pelarutan protein dalam suasana basa menggunakan $\mathrm{NaOH}$ (Sugijanto dan Manullang, 2001). Salah satu faktor yang berpengaruh dalam proses ekstraksi alkali yaitu nilai $\mathrm{pH}$ ekstraksi (Kinsella, 1979). Penggunaan $\mathrm{pH}$ ekstraksi yang tepat akan menghasilkan kadar protein dan sifat fungsional yang optimum. Semakin jauh perbedaan $\mathrm{pH}$ ekstraksi dari titik isoelektrik maka kelarutan protein akan semakin meningkat (Triyono, 2010). Sugijanto dan Manullang (2001), membuktikan bahwa penggunaan $\mathrm{pH} 10$ menghasikan konsentrat protein wheat pollard yang optimum yaitu $62,75 \%$ protein. Elsohaimy et al., (2015), juga membuktikan bahwa pada $\mathrm{pH} 10$ protein quinoa terekstrak secara optimal yaitu 267,35 $\mu \mathrm{g} \quad$ protein $/ \mathrm{ml}$ larutan pengekstrak. Yuslinawati (2006), juga menyebutkan bahwa pada $\mathrm{pH}$ ekstraksi 10 merupakan perlakuan yang menghasilkan konsentrat protein ampas tahu dengan rendemen, sifat fisiko-kimia dan fungsional terbaik.

Beberapa studi di atas menunjukkan bahwa nilai $\mathrm{pH}$ ekstraksi berpengaruh nyata terhadap rendemen, sifat fisiko-kimia dan fungsional konsentrat protein. Oleh karena itu, penelitian ini bertujuan untuk mengetahui pengaruh $\mathrm{pH}$ ekstraksi terhadap rendemen, sifat fisiko-kimia dan fungsional konsentrat protein kacang gude dan $\mathrm{pH}$ ekstraksi yang tepat untuk memperoleh konsentrat protein kacang gude dengan rendemen, sifat fisiko-kimia dan fungsional terbaik. 


\section{METODE PENELITIAN}

\section{Tempat dan Waktu}

Penelitian ini dilaksanakan di Laboratorium Pengolahan Pangan, Laboratorium Teknik Pasca Panen, Laboratorium Analisis, dan Laboratorium Mikrobiologi Pangan Fakultas Teknologi Pertanian Universitas Udayana, Kampus Sudirman. Pelaksanaan penelitian ini berlangsung selama 5 bulan, dimulai pada bulan April sampai September 2017.

\section{Alat dan Bahan}

Alat yang digunakan untuk pembuatan sampel konsentrat protein kacang gude dan analisisnya adalah cabinet drying (Memmert), centrifuge (Centurion Scientific), shaker (Health Shaker Rotator H-M-SR), kertas saring, ayakan 80 mesh, $\mathrm{pH}$ meter (PHS-3D), Erlenmeyer (Pyrex), magnetic stirrer, tabung sentrifuge, water bath, Colori meter ACCU PROBE, desikator, botol timbang, pipet tetes, pipet volume, alat destilasi, gelas ukur (Pyrex), tabung reaksi (Pyrex), vortex (Maxi Mix II), labu Kjeldahl, neraca analitik (Shimadzu), dan blender (Phillips).

Bahan yang digunakan adalah biji kacang gude petik kering. Bahan kimia yang digunakan untuk ekstraksi dan analisis konsentrat protein adalah aquades, $\mathrm{HCl} 1 \mathrm{~N}$, $\mathrm{NaOH} 1 \mathrm{~N}$, minyak kedelai, $\mathrm{NaOH} 50 \%$, $\mathrm{H}_{2} \mathrm{SO}_{4}$, Indikator $\mathrm{PP}, \mathrm{H}_{3} \mathrm{BO}_{3}, \mathrm{HCl} 0,1 \mathrm{~N}$, dan tablet kjeldahl.

\section{Pelaksanaan Penelitian}

Penelitian ini menggunakan Rancangan Acak Lengkap (RAL) dengan perlakuan berbagai nilai $\mathrm{pH}$ ekstraksi. Perlakuan $\mathrm{pH}$ ekstraksi terdiri atas 5 taraf yaitu : $\mathrm{P} 1(\mathrm{pH} 9)$, P2 (pH 9,5), P3 (pH 10), P4 (pH 10,5), dan P5 ( $\mathrm{pH}$ 11). Penelitian diulang sebanyak 3 kali, sehingga diperoleh 15 unit percobaan. Data yang diperoleh dianalisis menggunakan sidik ragam, dan apabila terdapat pengaruh perlakuan terhadap parameter yang diamati, maka akan dilanjutkan dengan uji Duncan (Steel dan Torrie, 1993). Pelaksanaan penelitian ini terdiri atas dua tahap yaitu :

\section{a. Pembuatan tepung kacang gude}

Proses pembuatan tepung kacang gude mengikuti metode Elsohaimy et al (2015) yaitu biji kacang gude disortasi kemudian dicuci, setelah itu dikeringkan dalam oven pengering $45^{\circ} \mathrm{C}$ selama 8 jam. Kemudian digiling dengan blender kering dan diayak menggunakan saringan ukuran 80 mesh.

\section{b. Pembuatan konsentrat protein kacang gude}

Pembuatan konsentrat protein kacang gude mengikuti metode Ogunwolu et al., (2009) yang telah dimodifikasi.Tepung kacang gude dicampur dengan aquades (1:10), $\mathrm{pH}$ larutan diatur pada perlakuan $\mathrm{pH}$ ekstraksi yang terdiri atas 5 taraf $\mathrm{pH}(9 ; 9,5 ; 10 ; 10,5 ;$ dan 11) dengan penambahan $\mathrm{NaOH} 1$ N. Proses ekstraksi berlangsung selama 1 jam. Campuran tersebut kemudian disentrifugasi menggunakan centrifuge dengan kecepatan 5000 rpm pada suhu $4^{0} \mathrm{C}$ selama 10 menit, kemudian dihasilkan filtrat dan endapan. Proses tersebut diulang sebanyak 1 kali. Filtrat yang diperoleh kemudian ditambahkan asam klorida $1 \mathrm{~N}$ hingga mencapai $\mathrm{pH}$ 4,5. Protein 
yang mengalami presipitasi dipisahkan menggunakan centrifuge dengan kecepatan 5000 rpm pada suhu $4^{0} \mathrm{C}$ selama 10 menit. Endapan kemudian dikeringkan menggunakan pengering oven bersuhu $45^{\circ} \mathrm{C}$ selama 4 jam dan diperoleh konsentrat protein kacang gude.

\section{Parameter yang Diamati}

Parameter yang diamati meliputi rendemen (Sudarmadji et al.,1997), tingkat kecerahan (Hutching, 1999), kadar protein dengan metode Mikro Kjehldahl (Sudarmadji et al., 1997), kadar air dengan metode oven (AOAC, 1995), daya serap air dengan metode Volumetri (Budijanto et al., 2011), daya serap minyak dengan metode Volumetri (Budijanto et al., 2011), kapasitas emulsi (Budijanto et al., 2011), stabilitas emulsi (Sathe dan Salunke, 1981 dalam Dyahwarni, 2006), kapasitas buih (Budijanto et al., 2011) dan stabilitas buih (Swamynglingappa dan Srinivas, 1994 dalam Yuslinawati, 2006).

\section{HASIL DAN PEMBAHASAN}

Nilai rata-rata rendemen, nilai kecerahan (L), kadar protein, kadar air, dan daya serap air konsentrat protein kacang gude dapat dilihat pada Tabel 1. Nilai rata-rata daya serap minyak kapasitas dan stabilitas emulsi, serta kapasitas dan stabilitas buih konsentrat protein kacang gude dapat dilihat Tabel 2.

Tabel 1. Nilai Rata-rata Rendemen, Nilai Kecerahan (L), Kadar Protein, Kadar Air, dan Daya Serap Air Konsentrat Protein Kacang Gude

\begin{tabular}{cccccc}
\hline $\begin{array}{c}\mathrm{pH} \\
\text { ekstraksi }\end{array}$ & $\begin{array}{c}\text { Rendemen } \\
(\%) \mathrm{bk}\end{array}$ & $\begin{array}{c}\text { Nilai kecerahan } \\
(\mathrm{L})\end{array}$ & $\begin{array}{c}\text { Kadar protein (\%) } \\
\text { bk }\end{array}$ & Kadar air (\%) bk & $\begin{array}{c}\text { Daya serap air (ml } \\
\mathrm{H}_{2} \mathrm{O} / \mathrm{g} \text { solid) }\end{array}$ \\
\hline 9 & $12,87 \pm 1,51 \mathrm{~b}$ & $21,54 \pm 0,56 \mathrm{a}$ & $81,65 \pm 1,65 \mathrm{~b}$ & $7,75 \pm 0,09 \mathrm{ab}$ & $1,49 \pm 0,06 \mathrm{c}$ \\
9,5 & $15,58 \pm 0,33 \mathrm{a}$ & $20,17 \pm 0,62 \mathrm{~b}$ & $82,64 \pm 1,67 \mathrm{~b}$ & $7,78 \pm 0,06 \mathrm{ab}$ & $1,61 \pm 0,07 \mathrm{bc}$ \\
10 & $17,29 \pm 0,86 \mathrm{a}$ & $18,84 \pm 0,92 \mathrm{c}$ & $86,15 \pm 1,25 \mathrm{a}$ & $7,96 \pm 0,15 \mathrm{a}$ & $1,96 \pm 0,15 \mathrm{a}$ \\
10,5 & $16,37 \pm 0,83 \mathrm{a}$ & $17,92 \pm 0,12 \mathrm{~cd}$ & $83,53 \pm 1,51 \mathrm{ab}$ & $7,60 \pm 0,13 \mathrm{~b}$ & $1,71 \pm 0,06 \mathrm{~b}$ \\
11 & $15,63 \pm 0,43 \mathrm{a}$ & $17,74 \pm 0,21 \mathrm{~d}$ & $82,85 \pm 1,39 \mathrm{~b}$ & $7,52 \pm 0,20 \mathrm{~b}$ & $1,64 \pm 0,05 \mathrm{bc}$ \\
\hline
\end{tabular}

Keterangan : Huruf yang berbeda di belakang nilai rata-rata dalam tiap kolom yang sama menunjukkan perbedaan yang nyata pada uji Duncan $(\mathrm{P}<0,05)$

Tabel 2. Nilai Rata-rata Daya Serap Minyak, Kapasitas Emulsi, Stabilitas Emulsi, Kapasitas Buih, dan Stabilitas Buih Konsentrat Protein Kacang Gude

\begin{tabular}{cccccc}
\hline $\begin{array}{c}\mathrm{pH} \\
\text { ekstraksi }\end{array}$ & $\begin{array}{c}\text { Daya serap } \\
\text { minyak (ml } \\
\text { minyak/g } \\
\text { solid) }\end{array}$ & $\begin{array}{c}\text { Kapasitas } \\
\text { emulsi (\%) }\end{array}$ & $\begin{array}{c}\text { Stabilitas emulsi } \\
(\%)\end{array}$ & $\begin{array}{c}\text { Kapasitas buih } \\
(\%)\end{array}$ & $\begin{array}{c}\text { Stabilitas buih } \\
(\%)\end{array}$ \\
\hline 9 & $1,47 \pm 0,26 \mathrm{c}$ & $44,33 \pm 0,29 \mathrm{~d}$ & $48,00 \pm 0,50 \mathrm{~d}$ & $68,61 \pm 0,58 \mathrm{~d}$ & $25,48 \pm 1,48 \mathrm{c}$ \\
9,5 & $1,82 \pm 0,33 \mathrm{bc}$ & $48,67 \pm 1,89 \mathrm{c}$ & $49,58 \pm 0,88 \mathrm{c}$ & $90,32 \pm 2,42 \mathrm{c}$ & $27,61 \pm 1,56 \mathrm{bc}$ \\
10 & $2,62 \pm 0,15 \mathrm{a}$ & $54,67 \pm 2,75 \mathrm{a}$ & $54,83 \pm 0,76 \mathrm{a}$ & $100 \pm 0,87 \mathrm{a}$ & $38,19 \pm 0,99 \mathrm{a}$ \\
10,5 & $2,04 \pm 0,23 \mathrm{~b}$ & $52,33 \pm 1,61 \mathrm{ab}$ & $51,42 \pm 0,72 \mathrm{~b}$ & $97,09 \pm 0,00 \mathrm{~b}$ & $29,33 \pm 1,15 \mathrm{~b}$ \\
11 & $1,81 \pm 0,10 \mathrm{bc}$ & $49,33 \pm 1,61 \mathrm{bc}$ & $50,92 \pm 0,14 \mathrm{~b}$ & $96,44 \pm 0,58 \mathrm{~b}$ & $28,19 \pm 2,03 \mathrm{bc}$ \\
\hline
\end{tabular}

Keterangan : Huruf yang berbeda di belakang nilai rata-rata dalam tiap kolom yang sama menunjukkan perbedaan yang sangat nyata pada uji Duncan $(\mathrm{P}<0,01)$ 


\section{Rendemen}

Hasil analisis ragam menunjukkan bahwa $\mathrm{pH}$ ekstraksi berpengaruh sangat nyata $(\mathrm{P}<$ $0,01)$ terhadap rendemen konsentrat protein kacang gude. Perlakuan dengan rendemen tertinggi diperoleh pada $\mathrm{pH}$ ekstraksi 10 yaitu sebesar17,29+0,86\%, sedangkan konsentrat protein dengan rendemen terendah diperoleh dari $\mathrm{pH}$ ekstraksi 9 yaitu sebesar $12,87 \pm 1,51 \%$.

Tingginya rendemen pada konsentrat protein kacang gude yang dihasilkan dengan perlakuan $\mathrm{pH}$ ekstraksi 10 kemungkinan disebabkan oleh kondisi $\mathrm{pH}$ larutan yang jauh dari $\mathrm{pH}$ isoelektris sebagian besar asam-asam amino tepung kacang gude. Triyono (2010), menyatakan bahwa semakin jauh perbedaan $\mathrm{pH}$ dari titik isoelektrik maka kelarutan protein akan semakin meningkat. Kelarutan protein yang meningkat menyebabkan rendemen yang diperoleh juga semakin besar.

Penggunaan $\mathrm{pH}$ yang ekstrem $(\mathrm{pH}>10)$ kemungkinan dapat menyebabkan terjadinya denaturasi protein. Hal ini didukung oleh pernyataan Kabirullah dan Wills (1982) dalam Dyahwarni (2006) yang menyatakan bahwa semakin tinggi $\mathrm{pH}$ yang digunakan untuk mengekstrak protein, maka semakin besar pula protein yang terekstrak, tetapi ada kemungkinan protein dapat terhidrolisis kembali dan mengalami denaturasi. Cheftel $e t$ al., (1985), menyatakan bahwa denaturasi protein dapat mengurangi kelarutan protein karena bagian hidrofobiknya tidak terlindungi.

\section{Kecerahan}

Hasil analisis ragam menunjukkan bahwa $\mathrm{pH}$ ekstraksi berpengaruh sangat nyata $(\mathrm{P}<$ 0,01) terhadap kecerahan konsentrat protein kacang gude. Perlakuan dengan kecerahan tertinggi diperoleh pada $\mathrm{pH}$ ekstraksi 9 yaitu sebesar 21,54+0,56, sedangkan konsentrat protein dengan kecerahan terendah diperoleh dari pH ekstraksi 11 yaitu sebesar 17,74+0,21.

Nilai kecerahan terus mengalami penurunan seiring dengan meningkatnya $\mathrm{pH}$ ekstraksi. Kecerahan konsentrat protein kacang gude yang dihasilkan kemungkinan dipengaruhi oleh adanya reaksi Maillard pada saat ekstraksi dimana terjadi interaksi antara protein dengan senyawa non protein yang ada pada bahan baku. Kusnandar (2010) melaporkan bahwa laju reaksi Maillard dipengaruhi beberapa faktor, salah satunya adalah pH. Winarno (2004) juga melaporkan bahwa pada kondisi basa, terjadinya reaksi antara gula pereduksi dengan senyawa yang mempunyai gugus $\mathrm{NH}_{2}$ membentuk melanoidin berlangsung lebih cepat. Dengan demikian, semakin tinggi $\mathrm{pH}$ ekstraksi menyebabkan tingkat kecerahan konsentrat protein kacang gude semakin menurun.

\section{Kadar Protein}

Hasil analisis ragam menunjukkan bahwa $\mathrm{pH}$ ekstraksi berpengaruh nyata $(\mathrm{P}<0,05)$ terhadap kadar protein konsentrat protein kacang gude. Perlakuan dengan kadar protein tertinggi diperoleh pada $\mathrm{pH}$ ekstraksi 10 yaitu sebesar 86,15+1,25\%, sedangkan konsentrat protein dengan kadar protein terendah 
diperoleh dari $\mathrm{pH}$ ekstraksi 9 yaitu sebesar $81,65+1,65 \%$.

Tingginya kadar protein pada konsentrat protein kacang gude yang dihasilkan dengan perlakuan $\mathrm{pH}$ ekstraksi 10 kemungkinan disebabkan oleh kondisi $\mathrm{pH}$ larutan yang jauh dari $\mathrm{pH}$ isoelektris sebagian besar asam-asam amino tepung kacang gude. Triyono (2010), menyatakan bahwa semakin jauh perbedaan $\mathrm{pH}$ dari titik isoelektrik maka kelarutan protein akan semakin meningkat. Hal ini juga didukung pernyataan Lehninger (1982) yang menyebutkan bahwa pengaruh $\mathrm{pH}$ didasarkan pada adanya perbedaan muatan antara asamasam amino penyusun protein, daya tarik menarik yang paling kuat antar protein terjadi pada $\mathrm{pH}$ isoelektrik, sedangkan pada $\mathrm{pH}$ di atas dan di bawah titik isoelektrik, protein akan mengalami perubahan muatan yang menyebabkan menurunnya daya tarik menarik antar molekul protein, sehingga molekul lebih mudah terurai.

Penggunaan $\mathrm{pH}$ ekstraksi di atas 10 akan menyebabkan protein terdenaturasi dan terbentuknya senyawa kompleks lisinoalanin. Senyawa ini menyebabkan penurunan nilai gizi dan pembentukan komponen yang tidak dikehendaki (Sugijanto dan Manullang, 2001). Pembentukan lisinoalanin dapat dipercepat dengan kondisi alkali dan suhu tinggi (Budijanto et al., 2011).

\section{Kadar Air}

Hasil analisis ragam menunjukkan bahwa $\mathrm{pH}$ ekstraksi berpengaruh nyata $(\mathrm{P}<0,05)$ terhadap kadar air konsentrat protein kacang gude. Perlakuan dengan kadar air tertinggi diperoleh pada $\mathrm{pH}$ ekstraksi 10 yaitu sebesar $7,96 \pm 0,15 \%$, sedangkan konsentrat protein dengan kadar air terendah diperoleh dari $\mathrm{pH}$ ekstraksi 11 yaitu sebesar 7,52+0,20\%.

Kadar air konsentrat protein kacang gude mengalami peningkatan seiring dengan peningkatan $\mathrm{pH}$ ekstraksi kemudian mengalami penurunan kembali pada $\mathrm{pH}$ di atas 10. Dyahwarni (2009) melaporkan bahwa kadar air konsentrat protein dapat dikatakan meningkat seiring dengan peningkatan $\mathrm{pH}$ ekstraksi. Peningkatan $\mathrm{pH}$ ekstraksi juga dapat menyediakan lebih banyak gugus protein bersifat polar baik yang bermuatan maupun yang tidak bermuatan. Asam amino polar bermuatan seperti asam aspartat, asam glutamat, lisin, arginin dan histidin, sedangkan asam amino polar tak bermuatan seperti serin, treonin, sistein, tirosin, asparagin, dan glutamin (Boyer, 2002). Hal ini juga didukung oleh Sze-Thao dan Sathe (2000) dalam Dyahwarni (2009) bahwa air dapat terikat pada asam amino yang bersifat polar.

\section{Daya Serap Air}

Hasil analisis ragam menunjukkan bahwa $\mathrm{pH}$ ekstraksi berpengaruh sangat nyata $(\mathrm{P}<$ 0,01) terhadap daya serap air konsentrat protein kacang gude. Perlakuan dengan daya serap air tertinggi diperoleh pada $\mathrm{pH}$ ekstraksi 10 yaitu sebesar $1,96 \pm 0,15 \mathrm{ml} \mathrm{H}_{2} \mathrm{O} / \mathrm{g}$ solid, sedangkan konsentrat protein dengan daya serap air terendah diperoleh dari $\mathrm{pH}$ ekstraksi 9 yaitu sebesar 1,49+0,06 $\mathrm{ml} \mathrm{H} \mathrm{H}_{2} \mathrm{O} / \mathrm{g}$ solid.

Daya serap air konsentrat protein dipengaruhi oleh komposisi asam-asam amino penyusunnya. Onsaard (2012) melaporkan 
bahwa faktor intrinsik yang berpengaruh terhadap daya serap air antara lain komposisi asam amino, konformasi protein, serta polaritas permukaan protein. Peningkatan $\mathrm{pH}$ ekstraksi hingga $\mathrm{pH} \quad 10$ diduga dapat mengekstrak asam-asam amino polar, dimana asam-asam amino tersebut memiliki $\mathrm{pH}$ isoelektris pada kisaran 2,8-11,2. Hal ini dikarenakan semakin jauh kondisi $\mathrm{pH}$ larutan dari $\mathrm{pH}$ isoelektrisnya maka kelarutan asamasam amino akan meningkat (Triyono, 2010).

Tingginya daya serap air pada perlakuan pH ekstraksi 10 kemungkinan disebabkan oleh banyaknya asam amino polar bermuatan seperti asam aspartat, asam glutamat, lisin, arginin dan histidin serta asam amino polar tak bermutan seperti serin, treonin, sistein, tirosin, asparagin dan glutamin (Boyer, 2002) yang terekstrak pada $\mathrm{pH}$ 10. Kilara (1994) dalam Triyono (2010) menyatakan bahwa sifat protein yang hidrofilik disebabkan oleh adanya rantai yang mempunyai gugus-gugus polar seperti karbonil, hidroksil, amino, karboksil dan sulfihidril, sehingga dapat membentuk ikatan dengan air. Jumlah dan tipe gugusgugus polar yang berbeda menyebabkan kemampuan protein untuk menyerap air pun berbeda.

\section{Daya Serap Minyak}

Hasil analisis ragam menunjukkan bahwa $\mathrm{pH}$ ekstraksi berpengaruh sangat nyata $(\mathrm{P}<$ $0,01)$ terhadap daya serap minyak konsentrat protein kacang gude. Perlakuan dengan daya serap minyak tertinggi diperoleh pada $\mathrm{pH}$ ekstraksi 10 yaitu sebesar 2,62+0,15 $\mathrm{ml}$ minyak/g solid, sedangkan konsentrat protein dengan daya serap minyak terendah diperoleh dari $\mathrm{pH}$ ekstraksi 9 yaitu sebesar 1,47+0,26 ml minyak/g solid.

Peningkatan $\mathrm{pH}$ ekstraksi hingga $\mathrm{pH} 10$ diduga dapat mengekstrak asam-asam amino non polar yang memiliki nilai $\mathrm{pH}$ isoelektris sekitar 5,7-6. Lin et al., (1974) menyatakan bahwa struktur protein yang lebih banyak bersifat lipofilik (non polar) memberikan kontribusi terhadap meningkatnya daya serap minyak. Onsaard (2012) juga melaporkan bahwa mekanisme daya serap minyak disebabkan oleh adanya sisi rantai non polar protein yang berikatan dengan rantai hidrokarbon asam lemak. Peningkatan $\mathrm{pH}$ ekstraksi di atas 10 dapat menurunkan daya serap minyak konsentrat protein. Mekanisme ini dapat terjadi akibat denaturasi protein saat proses ekstraksi. Proses denaturasi tersebut berpengaruh pada ikatan hidrogen dan ikatan hidrofobik, misalnya pada leusin, valin, fenialanin dan triptofan yang saling berikatan membentuk suatu missel dan tidak larut dalam air (Triyono, 2010).

\section{Kapasitas Emulsi}

Hasil analisis ragam menunjukkan bahwa $\mathrm{pH}$ ekstraksi berpengaruh sangat nyata $(\mathrm{P}<$ 0,01) terhadap kapasitas emulsi konsentrat protein kacang gude. Kapasitas emulsi tertinggi diperoleh pada $\mathrm{pH}$ ekstraksi 10 yaitu sebesar $54,67 \pm 2,75 \%$ sedangkan konsentrat protein dengan kapasitas emulsi terendah diperoleh dari $\mathrm{pH}$ ekstraksi 9 yaitu sebesar $44,33+0,29 \%$.

Peningkatan dan penurunan nilai kapasitas emulsi yang didapatkan pada penelitian ini 
berkorelasi positif dengan kadar protein yang juga meningkat seiring kenaikan $\mathrm{pH}$ ekstraksi, dimana pada $\mathrm{pH}$ ekstraksi 10 konsentrat protein kacang gude memiliki kadar protein tertinggi. Hal ini didukung oleh Subarna et al., (1990), bahwa kapasitas emulsi dipengaruhi oleh konsentrasi protein, kecepatan pencampuran, jenis protein, jenis lemak, dan sistem emulsi. Kadar protein yang tinggi pada konsentrat protein kacang gude hasil eskstraksi pada $\mathrm{pH} 10$ juga menggambarkan tingginya asam-asam amino baik polar (hidrofilik) maupun non polar (lipofilik) yang tersusun di dalamnya. Hal ini menyebabkan konsentrat protein kacang gude hasil ekstraksi pada $\mathrm{pH}$ 10 memiliki nilai kapasitas emulsi tertinggi. Kato dan Nakai (1980) melaporkan bahwa emulsifier harus memiliki kedua kelompok hidrofilik dan lipofilik untuk berinteraksi dengan air dan minyak.

\section{Stabilitas Emulsi}

Hasil analisis ragam juga menunjukkan bahwa $\mathrm{pH}$ ekstraksi berpengaruh sangat nyata $(\mathrm{P}<0,01)$ terhadap stabilitas emulsi konsentrat protein kacang gude. Perlakuan yang menghasilkan konsentrat protein dengan tingkat stabilitas emulsi tertinggi yaitu $\mathrm{pH}$ ekstraksi 10 yakni sebesar 54,83+0,76\% sedangkan konsentrat protein dengan stabilitas emulsi terendah diperoleh dari $\mathrm{pH}$ ekstraksi 9 yaitu sebesar $48,00 \pm 0,50 \%$.

Peningkatan dan penurunan nilai stabilitas emulsi konsentrat protein kacang gude yang dihasilkan pada penelitian ini berkorelasi positif dengan nilai kadar protein konsentrat protein kacang gude. Hal ini didukung oleh pernyataan Zayas (1997) yang menyebutkan bahwa semakin kecil konsentrasi protein maka nilai stabilitas emulsinya semakin kecil. Pembentukan emulsi yang stabil juga memerlukan protein dengan kelarutan yang baik dan mudah teradsorpsi pada lapisan, memiliki grup hidrofilik-lipofilik yang terdistribusi merata, dan mampu membentuk film kohesif yang kuat. Jones (1982) dalam Elsohaimy et al.,(2015) juga menyatakan bahwa protein memiliki efek yang dapat menstabilkan emulsi yaitu dengan pembentukan matriks membran yang mengelilingi tetesan minyak.

\section{Kapasitas Buih}

Hasil analisis ragam menunjukkan bahwa $\mathrm{pH}$ ekstraksi berpengaruh sangat nyata $(\mathrm{P}<$ 0,01) terhadap kapasitas buih konsentrat protein kacang gude. Perlakuan dengan kapasitas buih tertinggi diperoleh pada perlakuan $\mathrm{pH}$ ekstraksi 10 yaitu sebesar $100+0,87 \%$ sedangkan konsentrat protein dengan kapasitas buih terendah diperoleh dari pH ekstraksi 9 yaitu sebesar 68,61+0,58\%.

Peningkatan dan penurunan nilai kapasitas buih konsentrat protein kacang gude yang dihasilkan pada penelitian ini berkorelasi positif dengan nilai kadar protein, dimana pada perlakuan $\mathrm{pH}$ ekstraksi 10 konsentrat protein kacang gude yang dihasilkan memiliki kadar protein tertinggi. Korelasi antara kadar protein konsentrat dan kapasitas buih dapat digambarkan melalui peran protein dalam pembentukan busa yaitu protein akan berdifusi ke dalam fase antara udara-air untuk mengurangi tegangan antar muka pada fase 
aqueos dan non-aqueos, sehingga dapat meningkatkan viskositas dan elastisitas dari fase cair dan membentuk film yang kuat (Zayas, 1997). Damodaran (1996) juga melaporkan bahwapeningkatan konsentrasi protein akan meningkatkan interaksi antar molekul protein, sehingga dapat meningkatkan viskositas dan mendorong pembentukan multilayer yaitu lapisan kohesif pada permukaan.

\section{Stabilitas Buih}

Hasil analisis ragam menunjukkan bahwa $\mathrm{pH}$ ekstraksi berpengaruh sangat nyata $(\mathrm{P}<$ 0,01) terhadap stabilitas buih konsentrat protein kacang gude. Perlakuan dengan stabilitas buih tertinggi diperoleh pada $\mathrm{pH}$ ekstraksi 10 yaitu sebesar 38,19+0,99\% sedangkan konsentrat protein dengan stabilitas buih terendah diperoleh dari $\mathrm{pH}$ ekstraksi 9 yaitu sebesar $25,48+1,48 \%$.

Peningkatan dan penurunan nilai stabilitas buih konsentrat protein kacang gude berkorelasi positif dengan kadar proteinnya. Adebowale dan lawal (2003) dalam Hapsari (2009) menyatakan bahwa peningkatan konsentrasi protein akan meningkatkan interaksi protein-protein yang lebih besar yang dapat juga meningkatkan viskositas dan memfasilitasi pembentukan lapisan multilayer kohesif pada permukaan, selain itu peningkatan konsentrasi juga dapat mendorong pembentukan lapisan yang lebih tebal yang dapat membatasi pengeringan protein dari lapisan.

\section{KESIMPULAN DAN SARAN}

\section{Kesimpulan}

Berdasarkan hasil penelitian maka dapat disimpulkan hal-hal sebagai berikut:

1. $\mathrm{pH}$ ekstraksi berpengaruh nyata terhadap kadar protein dan kadar air, serta berpengaruh sangat nyata terhadap rendemen, kecerahan (L), daya serap air, daya serap minyak, kapasitas emulsi, stabilitas emulsi, kapasitas buih, serta stabilitas buih konsentrat protein kacang gude.

2. Konsentrat protein kacang gude terbaik diperoleh pada $\mathrm{pH}$ ekstraksi 10 dengan sifat antara lain rendemen (bk) 17,29\%, nilai L 18,84, kadar protein (bk) 86,15\%, kadar air (bk) $7,96 \%$, daya serap air $1,96 \mathrm{ml} \mathrm{H}_{2} \mathrm{O} / \mathrm{g}$ solid, daya serap minyak $2,62 \mathrm{ml}$ minyak/ $\mathrm{g}$ solid, kapasitas emulsi 54,67\%, stabilitas emulsi $54,83 \%$, kapasitas buih $100 \%$, dan stabilitas buih $38,19 \%$.

\section{Saran}

Berdasarkan hasil penelitian, maka dapat disarankan hal- hal sebagai berikut:

1. Pembuatan konsentrat protein kacang gude sebaiknya menggunakan pH 10 sebagai nilai pH ekstraksi.

2. Perlu dilakukan kajian lebih lanjut mengenai kandungan asam-asam amino dalam konsentrat protein yang dihasilkan, serta aplikasinya pada olahan pangan. 


\section{DAFTAR PUSTAKA}

Anonimous. 2015. Statistik Perdagangan Luar Negeri "Impor" 2015 Jilid I. Badan Pusat Statistik Indonesia, Jakarta.

Anonimous. 2016. Statistik Perdagangan Luar Negeri "Impor" 2016 Jilid I. Badan Pusat Statistik Indonesia, Jakarta.

Anonimous. 2017. Buletin Statistik Perdagangan Luar Negeri "Impor" Agustus 2017. Badan Pusat Statistik Indonesia, Jakarta.

Assotiation of Official Analytical Chemist [AOAC]. 1995. Official Methods of Analysis. 16th editions. Assotiation of Official Analytical Chemis. Inc. Arlington, Virginia.

Boyer, R. 2002. Concepts in Biochemistry (Second Edition). Brooks Coe, Thomson Learning, USA.

Budijanto, S., A.B. Sitanggang., dan W. Murdiati. 2010. Karakterisasi Sifat Fisiko-Kimia dan Fungsional Isolat Protein Biji Kecipir (Psophocarpus tetragonolobus L.). Jurnal Teknologi dan Industri Pangan 22 (2) : 130-136.

Cheftel, J.C., J. L. Cuq dan D. Lorient. 1985. Amino Acid, Peptide and Protein. In : O. R. Fennema (ed). Food Chemistry. Third Edition. Marcell Dekker Inc, New York.

Damodaran, S. 1996. Amino Acid, Peptides, and Proteins. In : O. R. Fennema (ed). Food Chemistry. Marcell Dekker Inc, New York.

Damardjati , D. S dan S. Widowati. 1985. Prospek Pengembangan Kacang Gude di Indonesia. Balai Penelitian Tanaman Pangan, Sukamandi.

Dyahwarni, N. 2006. Pengaruh Waktu dan pH Ekstraksi terhadap Rendemen dan Sifat Konsentrat Protein dari Dedak Gandum (Wheat Polllard). [Skripsi]. Departemen Teknologi Industri Pertanian Fakultas Teknologi Pertanian Institut Pertanian Bogor, Bogor.

Elsohaimy, S. A., T.M Refaay, dan M.M.M. Zaytoun. 2015. Physicochemical and Functional Properties of Quinoa Protein Isolate. Annals of Agricultural Science 60 (2) ; 297-305.
Emefiene, M. E., V. I. Joshua, C. Nwadike, A.Y. Yaroson dan N.D.E. Zwalnan 2014. Profitability Analysis of Pigeon Pea (Cajanus cajan) Production in Riyom Lga of Plateau State. Academic Journal of Interdiciplinary Studies MCSER Publishing Rome Italy 3 (7) : 44-54.

Fathurrahman. 2005. Hasil Biji Kacang Gude (Cajanus cajan (L) Millsp.) Kultivar Mega dan Galur ICPL 84031 Akibat Pemulsaan Jerami Padi dan Pemupukan P pada Berbagai Jarak Tanam. Jurnal Pembangunan Pedesaan 5 (1) : 54-59.

Hapsari, A.W. 2009. Studi Sifat Fisiko-Kimia, Fungsional Protein, dan Kapasitas Antioksidan pada Konsentrat Protein Kecambah Kacang Komak (Lablab purpureus (L) Sweet). [Skripsi]. Departemen Ilmu dan Teknologi Pangan Fakultas Teknologi Pertanian Institut Pertanian Bogor, Bogor.

Hutching, J. B. 1999. Food Color and Appearance. Second Edition. Aspen Publisher, Inc., Maryland.

Kato, A. dan S. Nakai. 1980. Hydrophobicity Determined by a Fluorescence Probe Method and Its Correlation with SurfaceProperties of Proteins. Biochimica et Biophysica Acta, 624 :13-20.

Kinsella, J. E. 1979. Functional Properties of Soybean Protein. J. American Oil. Chem. Soc. $56: 242-257$.

Koswara, S. 2009. Teknologi Pengolahan Kedelai (Teori dan Praktek). EbookPangan.com.

Kusnandar, F. 2010. Kimia Pangan. Dian Rakyat, Jakarta

Lehninger, A. L. 1982. Dasar-Dasar Biokimia. Penerjemah Maggy, T. Erlangga, Jakarta.

Lin, M. Y., E. S. Humbert dan F. W. Soluski. 1974. Certain Functional Properties of Sunflower Meal Products. J. Food Sci. 39 : 368-373.

Ogunwolu, S.O., F. O. Henshaw, H. P. Mock., dan A. Santros. 2009. Functional Properties of Protein Concentrates and Isolates Produced from Cashew (Anacardium occidentale L.) Nut. J. Food Chem. $115: 852-858$. 
Onsaard, E. 2012. Sesame Proteins. International Food Research Journal 19 (4) : 1287-1295.

Steel, R.G.D dan J.H. Torrie. 1993. Prinsip dan Prosedur Statistika Suatu Pendekatan Biometrik. Penerjemah B. Sumantri. PT. Gramedia Pustaka, Jakarta.

Subarna, N. Andarwulan, dan N.S. Palupi. 1990. Karakterisasi Sifat Fisiko-Kimia dan Fungsional Minyak dan Protein Kacang Tanah. Laporan Penelitian IPB, Bogor.

Sudarmadji, S., B. Haryono., dan Suhardi. 1997. Prosedur Analisis untuk Bahan Makanan dan Pertanian. Liberti, Yogyakarta.

Sugijanto, V. V., dan M. Manullang. 2001. Pembuatan Protein Wheat Pollard sebagai Pemanfaatan Hasil Samping Penggilingan Gandum. Jurnal Teknologi dan Industri Pangan 7 (1) : 54-60.

Susila, A. D., M. Syukur, H. Purnamawati, K. Dharma, E. Gunawan, dan Evi. 2012. Koleksi dan Identifikasi Tanaman Sayuran Indigenous. Pusat Kajian Hortikultura Tropika Institut Pertanian Bogor, Bogor.

Triyono, A. 2010. Mempelajari Pengaruh Penambahan Beberapa Asam pada Proses Isolasi Protein terhadap Tepung Protein Isolat Kacang Hijau (Phaseolus radiatus L.). Prosiding Seminar Rekayasa Kimia dan Proses, 1411-4216.

Winarno, F. G. 2004. Kimia Pangan dan Gizi. PT. Gramedia Pustaka Utama, Jakarta.

Yuslinawati. 2006. Isolasi dan Karakterisasi Sifat-Sifat Fungsional Protein Ampas Tahu. [Skripsi]. Fakultas Teknologi Pertanian Institut Pertanian Bogor, Bogor.

Zayas, J. F. 1997. Functionality of Proteins in Food. Springer, New York. 